\title{
Distribution of Montagnea arenaria (DC.) Zeller mushrooms in Mongolia, some new records from depression of the Great Lakes semi-desert steppe
}

\section{Новые местонахождения Montagnea arenaria (DC.) Zeller в депрессии великих озер полупустынной степи Монголии}

\author{
Kherlenchimeg N., Urgamal M. \\ Херленчимег Н., Ургамал М. \\ Ботанический сад-институт Академии наук Монголии, г. Улан-Батор, Монголия. E-mail: nkherlenchimeg@gmail.com \\ Botanic garden and research institute, Mongolian Academy of Sciences, Ulan Bator, Mongolia.
}

\begin{abstract}
Summary. The euagaric Montagnea arenaria (DC.) Zeller (Basidiomycota) one of the rarest fungi in Mongolia, was found in new locality in xerothermic sward of depression of the Great Lakes semidesert steppe. The habitat, ecology and geographical distribution of $M$. arenaria in Mongolia are reviewed. The Mongolian material is completely described and illustrated, and a brief taxonomic discussion is provided.
\end{abstract}

Keywords. Agaricoid fungi, distribution, Montagnea arenaria, new record, Mongolia.

Peфepam. Новое местонахождение одного из самых редких видов грибов в Монголии Montagnea arenaria (DC.) Zeller (Basidiomycota) было обнаружено на ксеротермическом дне депрессии полупустынной степи Великих озер. В статье рассмотрены среда обитания, экология и географическое распространение M. arenaria в Монголии. Монгольский материал полностью описан и проиллюстрирован, а также дано краткое таксономическое обсуждение.

Ключевые слова. Агариковые грибы, Монголия, новые местонахождения, распространение, Montagnea arenaria.

Introduction. Montagnea arenaria (DC.) Zeller is a gastroid mushroom with stipitate basidiocarp and a powdery gleba, adapted to arid and desert regions and is distributed worldwide (Chang 1999; Malgorzata, Bozena, 2002; Ángel et Mary 2006). Montagnea arenaria (DC.) Zeller is distributed in Africa including the Canary Islands, Europe, Asia, North and South America and Australia (Dörfelt, Gube, 2007). The new finding of $M$. arenaria from Mongolia confirms the general distribution of that species in the steppe and desert areas of Central Asia (Dörfelt, Gube, 2007; Kherlenchimeg, 2013).

Montagnea arenaria (DC.) Zeller is adapted to arid mostly dry, sandy places, and is found in dunes, deserts, semideserts and steppes (Malgorzata et al., 2002).

Systematics of the covered species Montagnea emerged in adaptation to arid climates from various groups of Agaricales, Boletales or Russulales and may be classified systematically to the families of these orders. Species of Montagnea described above belong to Agaricaceae (Dorfelt, Gube, 2007).

Montagnea arenaria was described by H. Dorfelt, M. Gube in 2007, for Mongolia for the first time. "Finding: 04. VIII. 2005: near Khovd, 45 km northwest of Khovd city, 26 km southwest of Erdenebüren [N $48^{\circ} 19^{\prime} 05^{\prime \prime}$; E 91 17'59"], approximately 1.580 m." It was grown on pastures and steppe with dominated a Krascheninnikovia ceratoides (L.) Gueldenst (Dorfelt, Gube, 2007).

The Great Lakes Depression (Mongolian: Ikh Nuuruudyn Khotgor), also called the Great Lakes' Hollow is a large semi-arid depression in Mongolia that covers parts of the Uvs, Khovd, Bayan-Ölgii, Zavkhan and Govi-Altai aimags.

Materials and methods. The following reagents were used for microscopic examinations of the fruiting bodies: Melzer's solution; $4 \% \mathrm{KOH}$ in water for reviving dried tissue. 


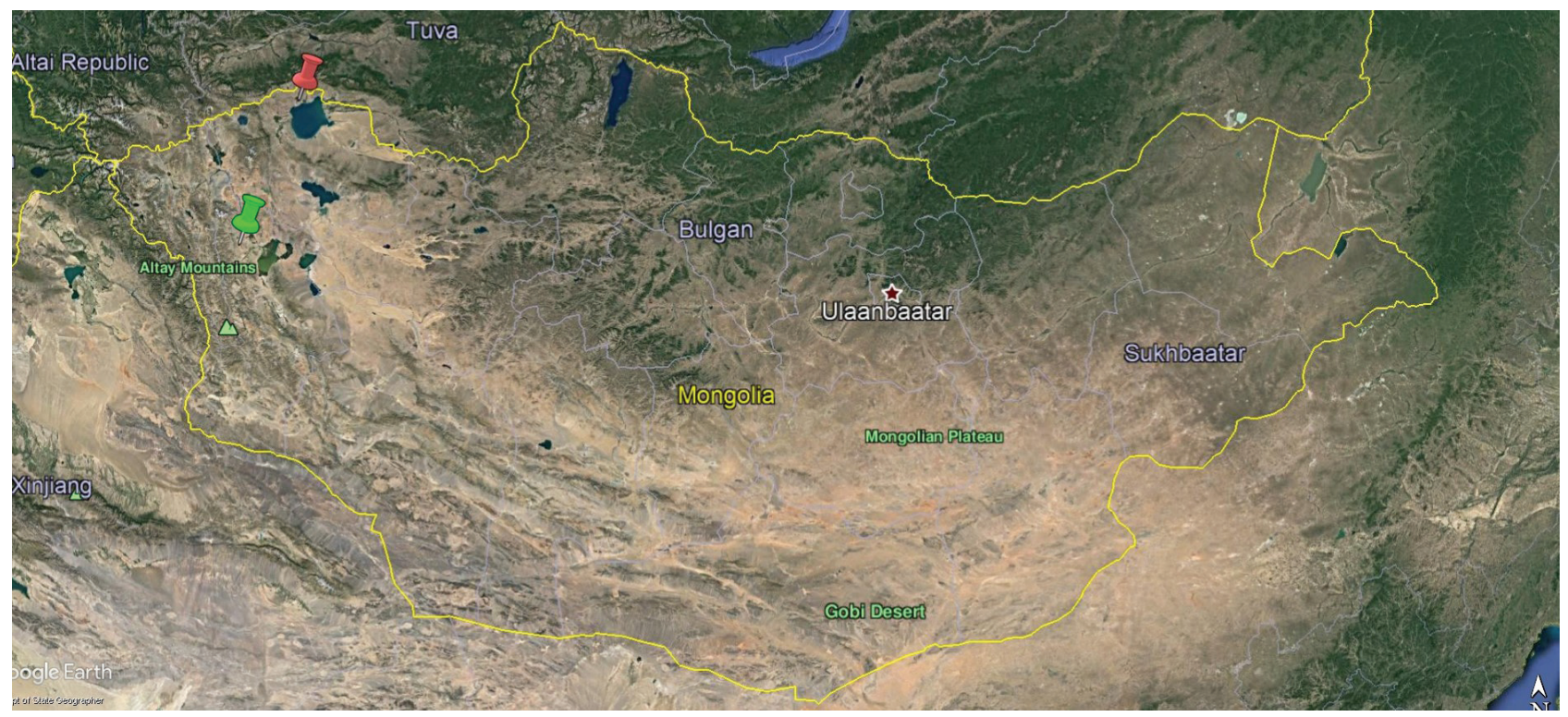

Fig. 1. Distribution of Montagnea arenaria (DC.) Zeller in Mongolia.

- new locality, - old locality (by Dorfelt, Gube, 2007).
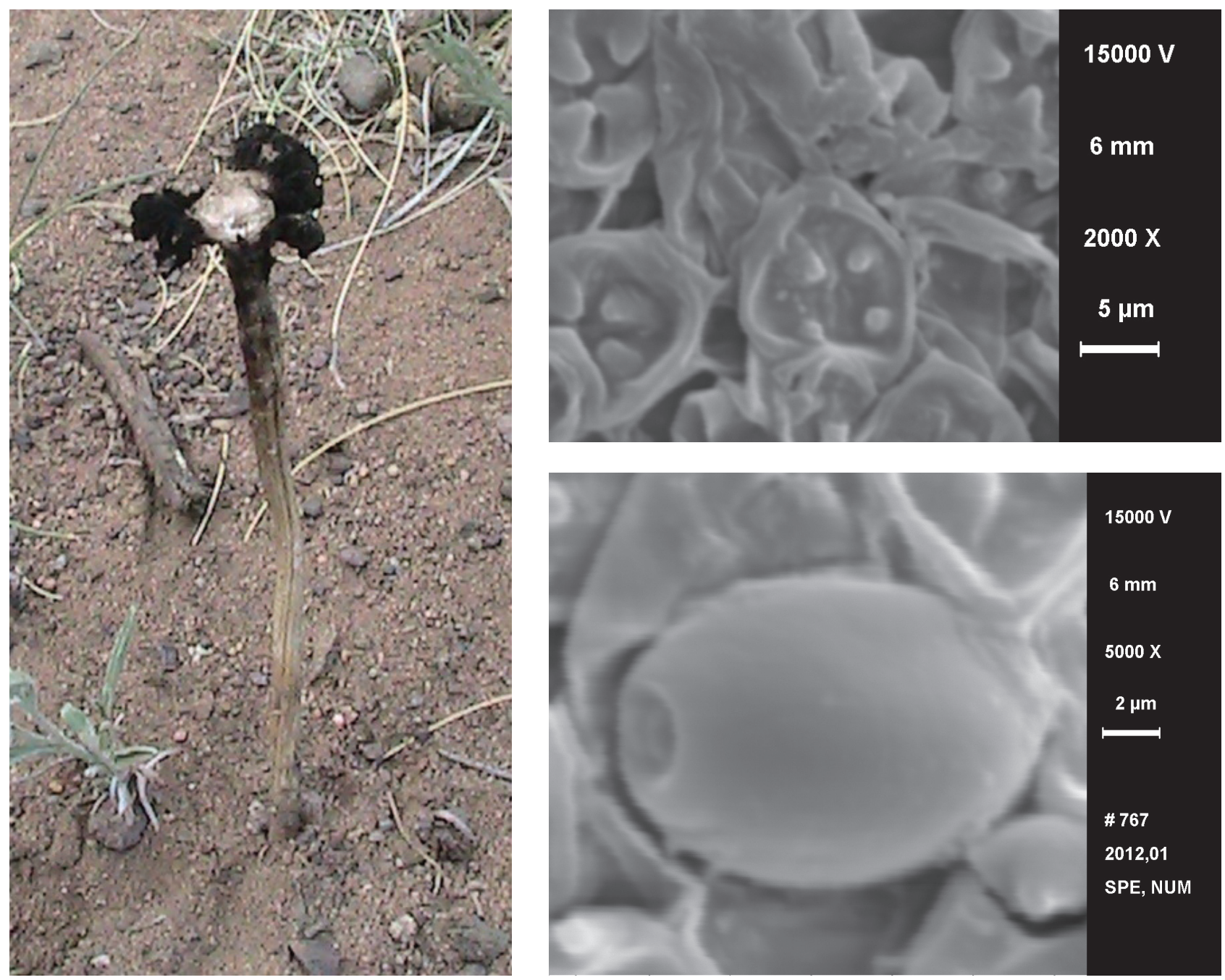

Fig. 2. Basidiom of Montagnea arenaria: a. fruitbody, b. basidio, c. spore. 
Sample was studied in the field by taking measurements on the morphological structures of the cap, stem and recording gills color, shape and dimensions. Macromorphological descriptions were made from fresh basidiomes. Samples were photographed and then specimens kept in small boxes inside. Scanning electron microscopy - Lamellar fragments (approx. 1-2 mm) were removed from dried basidiomes, attached to aluminum mounts using double-stick tape and gold-palladium sputter coated at a nominal coating thickness of $15 \mathrm{~nm}$ using a Hummer VII sputtering system (Anatech Ltd., Alexandria, Virginia). Basidiospores were examined at $15 \mathrm{kV}$ using a Carl Zeiss DSM-940 scanning electron microscope. Spores were microscopically tested by recording the shape, color and size of more than 20 arbitrary chosen spores.

Results. Montagnea arenaria (DC.) Zeller, 1943, Mycologia 35(4): 418. - Agaricus arenarius DC., 1815, in de Candolle et Lamarck, Fl. Franc., Edn 3 (Paris) 6: 45.

Specimen: Pileus 1.7-3.0 cm across, disk initially egg-shaped, soft, plane, with flattened umbo or sometimes broadly convex, with an undulating, striate margin, the center dry, dull gray, brown. Top of stipe disk-shaped, yellow to yellowish brown (Fig. 2a). Lamellae free, marginal zone with lamellae to ca 2/3 of the distance to the center when old, blackish-brown to black, not deliquescent, gleba between lamellae, regular to crisped, margin eroded. Stipe 4-12 x 0.4-1 cm, equal, yellow white to yellowish, fleshy when young then hollow, becoming hard and ligneous with age, smooth when young, then furrowed and fibrillous scaly, volva

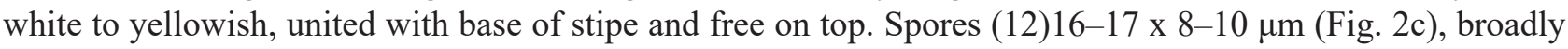
egg-shaped to ellipsoid, dark brown, smooth, with conspicuous germ pore. Spore powder black. Basidia clavate or pyriform, 4-spored, sterigmata short.

New finding. "Uvs aimag, Davst sum, N 4393'63,9" E 9956'68,9" alt. 1259 m, in sandy soil, It grows on pastures and steppe with dominated Krascheninnikovia ceratoides (L.) Gueldenst, 26. july. 2011, Herbarium - UBA/1102, collected by N. Kherlenchimeg" (Fig. 1).

Habitat: Montagnea arenaria is adapted to arid and sandy places.

\section{REFERENCES}

Ángel M. N., Mary C. A. Montanegra arenaria (Agaricaeceae, Basiodiomyocota), a New Record for Puerto Rico // Caribbean Journal of Science. - Puerto Rico, Mayagüez, 2006. - V. 42(2). - P. 244-246.

Malgorzata S., Bozena P. New record of Montagnea arenaria (Fungi, Agaricales) and its distribution in Poland // Polish Botanical Journal, 2002. - V. 47(2). - P. 211-213.

Chang $\boldsymbol{C h}$. Genetical and molecular systematic study on the genus Montagnea Fr. a desert adapted Gasteromycete // M. Sc. Thesis, Virginia Polytechnic Institute and State University, Blacksburg, Virginia, 1999. - 74 p.

Dörfelt H., Gube M. Secotioid Agaricales (Basidiomycetes) from Mongolia // Feddes Repertorium, 2007. - V. 118(34). - P. 103-112.

Kherlenchimeg $N$. New records of the family Agaricaceae of Mongolia // Proc. of the Inst. of Botany, Mongolian Academy of Sciences, 2013. - V. 25. - P. 8-12. (in Mongolian) 